\title{
COVID and the Crisis Mode in International Legal Scholarship
}

\author{
Frédéric Mégret
}

Perhaps predictably, within weeks of the COVID outbreak, international lawyers were busy planning special issues, edited collections, and countless blog posts. ${ }^{1}$ This is, after all, a crisis that affects us all in very individual and personal ways. It affects us as a discipline in at least the pedestrian sense that all of our conference planning and much that went with it has come crashing down. A profession that ordinarily feeds off its breezy cosmopolitanism suddenly found itself grounded, with no end in sight and some time to spare. It soon devoted its considerable potential for attention on the sujet du jour.

I myself gladly complied, ${ }^{2}$ including to this very project, no doubt enjoying the sense of continued collegiality, albeit of the virtual kind. It is surely one of the more appealing facets of our profession that we can regularly count on each other to contribute to our many respective projects. Also, the neoliberal university encourages the production of "timely" policy inputs, even as we may be ambivalent about that push and what it may require us to do. At the same time, I could not help noticing how the emerging coviD-and-internationallaw agenda threatened to engulf every other topic that we had been attending to until then. As brilliant colleagues occasionally seemed to fall over each other to publish the first article or the first book treatment of the topic, I sometimes had the impression of a mad-train careening at full speed without a driver. Was it, maybe, already too late to jump?

1 Many of these are still in the making but even a quick look around reveals a range of initiatives. See 'Covid-19' (International Law Blog) < https://internationallaw.blog/category/covid -19/> accessed 8 October 2020; 'COVID-19: Its Impact on International Law and You' (American Bar Association) < https://www.americanbar.org/groups/international_law/membership/ coronavirus-information-page/ $>$ accessed 8 October 2020 .

2 Frédéric Mégret, 'Homeward Bound? Global Mobility and the Role of the State of Nationality During the Pandemic' (2020) 114 AJIL Unbound 322; Frédéric Mégret, 'COVID-19 Symposium: Returning "Home"-Nationalist International Law in the Time of the Coronavirus' (Opinio Juris, 30 March 2020) <http://opiniojuris.org/2020/03/30/covid-19-symposium -returning-home-nationalist-international-law-in-the-time-of-the-coronavirus/> accessed 7 October 2020.

(C) FRÉDÉRIC MÉGRET, 2022 | DOI:10.1163/9789004472365_007

This is an open access chapter distributed under the terms of the CC BY-NC-ND 4Fo license. Mégret - 9789004472365 Downloaded from Brill.come4/26/2023 10:59:25AM 
In this short contribution, I want to reflect on how "crises" take hold of our imaginations and end up monopolizing our research attention. Drawing on Hillary Charlesworth's famous insights on international law "as a discipline of crisis", ${ }^{3}$ I focus on a somewhat narrower issue, namely crisis as a mode of scholarship specifically and its relationship to crises - real or imagined. There is little doubt that there is a covid crisis, but could it be that it is not a particularly meaningful crisis for international law? Even if it betrays a crisis for international lawyers, how is it distinctively an international law crisis rather than a crisis of globalization, modernity, or the State? What does it say about our discipline that we feel the need to immerse ourselves in crises and what are the limitations of doing so?

There are already several emerging genres in the international-law-andcovid field. These include pieces addressing discreet problems both directly connected to the disease and to the broader pandemic; thinking about how international law can more broadly help alleviate some of its consequences; and work on how the pandemic might, more deeply, impact international law itself. Obviously, the jury is still out on how significant the impact of covid will be for international law. I have read some good, insightful papers; and I have read others that felt more contrived, as if the author's heart ultimately wasn't in them. I suppose there are many ideas that we might otherwise have entertained, that can now be seen from a Covid perspective.

Yet it may also be that this rush to be present in the debate has more to do with international lawyers as a discipline than the significance of any contribution we might make to understanding the pandemic. The volume of what we produce speaks, maybe, to our obsession with relevance and also a certain plasticity of the discipline. There is no issue that cannot be treated as an international law issue, partly it should be said because international law has been led to mean almost anything. But the whole exercise sometimes reminds me of the tired "is there a doctor in the plane?" joke: "I am a doctor, I have a PhD in international law!" kept repeating the international lawyer, as everyone on board succumbed to a dangerous virus. Pushing ourselves on the front stage is part of an elaborate ritual of relevance that we often engage in, at our own risk.

The point is not that there are not issues that deserve attention but that the inflated sense of a "crisis" at a moment of intense mobilization creates its own distortions. What makes a crisis a "crisis", what is it a crisis of, who produces crisis discourse and to what ends? The intuitive, immediate framing of a major

3 Hilary Charlesworth, 'International Law: A Discipline of Crisis' (2002) 65 MLR 377. Also, Benjamin Authers and Hilary Charlesworth, "The Crisis and the Quotidian in International Human Rights Law' (2014) 44 Netherlands Yearbook of International Law 19. 
health crisis as an international law one raises more questions than it answers. This is not, for example, like Charlesworth's focus on the NATO intervention in Kosovo which at least raises some immediate and obvious questions for the jus ad bellum, a central stake of international law if ever there was one (although even there defining the exact parameters of that crisis was more challenging than it seemed). By comparison, the pandemic unfolds as a phenomenon that is more evidently removed from a central legal interrogation. That makes its characterization as an international legal crisis both potentially more interesting, but also more perplexing. The challenge, it turns, out is less "addressing" the crisis than the preliminary and contentious exercise of "defining" it as such.

One distinctively international legal issue to have garnered attention is the potential international responsibility of China. I was asked a couple of times as part of media requests. I initially turned them down as not worthy of a response, only to find that the idea was getting serious traction in the darker corners of the web and Florida courts. The issue has, in fact, since been entertained seriously in some blogs. ${ }^{4}$ Personally, I cannot think of a framing that is more woefully inadequate and that more explicitly betrays international law's inadequacies. In the vast sea of responsibilities for COVID and the harm it has provoked, singling out one particular actor for what was at heart a systemic problem seemed little short of scapegoating. The question is not whether China could not have done things better, or the wHo for that matter. I'm sure they could. The question is what good does it do to even think in those terms? What kind of populist design are we lending our expertise to? One of the most distinctly legal issue to emerge from the pandemic, in other words, seemed to be esoteric and a distraction, and to expose our own professional irrelevance or meaninglessness. On the rare occasions that the media seemed to pay attention to international law, therefore, my role seemed to be that of dampening down enthusiasms with a mix of "it's complicated" and "it's not a good idea."

Beyond that, I could see a lot of discussions that led one to merely restate the doxa of international law: that we would need more international cooperation; more laws; more rights etc. This is the international lawyer in their admonishing, hand-wringing role: familiar, predictable, and not particularly useful. Maybe, then, this was just not our crisis or at least not in the way we understood it. I'm sure there will be a few institutional articles to write about the wHO's performance, but I doubt those would live up to the expectations of the moment. The one area where I would have hoped to have seen much more

4 Peter Tzeng, 'Taking China to the International Court of Justice over COVID-19' (EJIL: Talk!, 2 April 2020) <https://www.ejiltalk.org/taking-china-to-the-international-court-of-justiceover-covid-19/> accessed 7 October 2020. 
is the covax Global Vaccines Facility, an ambitious program to share the costs and benefits of a vaccine. Here I thought is where the fundamental distributive questions lie. But however hard I searched, it seemed few international lawyers were speaking to the issue (I am optimistic it is only a question of time before some do but still it is intriguing that this has not captured the discipline's imagination more). I suspect that when it comes to the design of even mildly ambitious distributive schemes, the lawyers will not be in the front seat, and only be called in in an accessory capacity.

There are many ways in which even as we seek to academically capitalize on that crisis, it deeply eludes us as international lawyers. One is that it is a global and transnational phenomenon translating into renewed nationalism rather than a classic international crisis; this risks confirming the recurrent fear that our conceptual blueprint is increasingly unsuited for the world upon which we seek to intervene. Specifically, one concern is the world presiding over the pandemic has become so deeply privatized that the "public" in public international law seems increasingly irrelevant. As I turned to the debate on repatriation to the State of origin, for example, it struck me how the whole issue has been absorbed by purely private speculation on the obligations of airlines and insurance companies. To be sure, there were recriminations here and there that States could have provided more consular assistance, but these were clearly secondary. All of this also made me wonder about our role as gate keepers of what counts as good and bad international law topics and whether international law still has the capacity to fundamentally retool itself for the moment. One could also not help notice how the discipline went into overdrive after the crisis began to touch the inner sanctum of Western power. In short, I wondered if international lawyers would like what their discourse of crisis ended up revealing about themselves.

Aside from producing not very good research questions (a crisis, even properly conceived, is not a research question), I would suggest the crisis-mode in international legal scholarship suffers from a deeper and more pervasive flaw. It operates, essentially, as what is imagined as a "system absorbing exogenous shocks," where the crisis is imagined as a feature of the world outside the law and the law's task is if not to (help) solve it, at least to understand it from within its categories. What that view is at risk of getting most wrong is the idea that the challenge is coming from without. It risks reproducing an image of international law as perfectly self-constituted and dealing with outside "objects" that are not, in some crucial ways, objects of its own making. This may be an exaggeration in that no doubt many reflective international lawyers will point out ways in which Covid threatens to disrupt international law. But many do so in a way that has a kind of "I told you so" quality, where coviD is confirmation, for 
example, that we need more work to make international law real, true to itself or more effective. What this obviates is a sense that the crisis is at least partly of international law's making, so that it cannot entirely claim innocence from it. As Justina Uriburu and Francisco-José Quintana have brilliantly argued:

dominant approaches to both international legal thought and practice have made valuable but dangerously depoliticizing contributions, which portray the pandemic as a largely external phenomenon, concealing the role of international law in the production of the conditions that led to the pandemic and the allocation of the suffering that this crisis has caused. ${ }^{5}$

What, then, if the crisis was less an external crisis than a crisis within, helpfully revealed by world events? And what if, instead of being an opportunity for more scholarship, it was used as an opportunity to rethink scholarship? In order to explore that question I want to provide a very brief and schematic presentation of how the crisis genre in international legal scholarship operates as one of three modes: digestion, hegemony, and retreat. ${ }^{6}$

Under the "digestion" model, much of international legal scholarship is conceived in the fashion of a regular updating of an ongoing project under the conditions of the present. The image that comes closest in my mind is of a constant process of digestion of the "real" into the categories of the "law." 9/11 is a good example of an event that international lawyers have been digesting for the better part of the last 20 years (and before that, the end of the Cold War). The question is how $9 / 11$ has changed international law and, although the jury is still out, the general reassuring answer is ultimately not so much. In the process, the discipline grinds its wheels (and maybe imagines itself as flexing its intellectual muscles) and reassures itself that it is up to the task. It is predictable that some of this will happen to the "international law and coviD" debate and that, after having precipitously dramatized the stakes, not all of the resulting production will age well. The main idea, at any rate, is that the crisis provides an opportunity to reassert normalcy and therefore dominance, as part of a social competition over legitimate expertise.

5 Francisco-José Quintana and Justina Uriburu, 'Modest International Law: COVID-19, International Legal Responses, and Depoliticization' (2O20) 114 AJIL 687, 687.

6 For a very helpful exploration of the current context of international legal scholarship, see Jan Klabbers, 'On Epistemic Universalism and the Melancholy of International Law' (2018) 29 EJIL 1057. 
A second move is more specifically hegemonic. Where digestion denotes a relatively passive attitude, the hegemonic international lawyer is actively seeking out new terrains of the mind to conquer. International lawyers claim a certain problem which one would not normally have associated with them as their own. Because the number of good legal issues that we can put our minds to is finite (and there are only so many articles one can write about the same ICJ judgment or the Kosovo intervention for example), we often find ourselves scavenging for more. This is a constant process of appropriating parts of the non-legal world into the legal world, evidently helped by the fact that this is a largely illusory separation line in the first place. This is the vast realm of "international law and ...". We have all done it in some form or other. Sometimes, it involves looking around for the remains of other disciplines' feasts, but it also lends itself well to international law's inherent grandiosity as a normative discipline that tolerates no void and therefore thinks it must have (even through some Lotus style default rule) an answer to everything. There is no doubt some of this going on in relation to the covid pandemic. Where Charlesworth faults international lawyers for too "thin" a rendering of what counts as a crisis in the case of Kosovo, understanding the pandemic as a crisis for international law involves a hyper-broad characterization that steps resolutely into the quotidian of pretty much all of humanity. The problem with this hegemony is that it stretches our expertise thin - and therefore the willingness of others to listen to us.

The third move is retreat and it is one that is more popular than it seems. It involves abandoning the "real" world to others and retiring to what we do best, which is engaging in discreet debates highly peculiar and internal to the discipline, for example writing articles about institutions that have "international law" in their raison d'être, such as international courts. Think of this as a form of familiar hibernation from the real. We might, for example, focus only on the handful of judicial cases that will no doubt emerge in due course in relation to COVID (vaccine litigation? Repatriation lawsuits?), and chose to see the whole crisis through their reassuring but probably powerfully distorting prism (why did these cases emerge where they did and when they did? How could they have been otherwise? What cases are not raised?). The point is not that there is no value to informed doctrinal discussion of latest judicial developments but that the ratio of the discipline is still too heavily tilted towards that kind of work that reeks of formalism and reductionism and that focuses on rarefied legal disputes at the expense of the vast realms of everyday law. The retreat, moreover, seems to concede too much to those who would like us in our modest place when, for once, we may have more to contribute (beyond delusions of 
grandeur). If the problem with hegemony was an expertise spread too thin, the problem with retreat is that it ultimately compromises our claim to relevance.

There is not much of a middle ground between these extremes. But all lead to a degree of opportunism and follow-ism, of simply tagging along the party lest we miss out on the action even as, diffusely, we understand the real party is happening elsewhere, in the halls of power, in the temples of justice even, where we have not been invited or are called in when the key decisions have already been made. I am concerned by how impoverishing of even our scholarship (let alone our real-world influence) this follow-ism is. In effect, it robs us of the initiative of what we write on, showing us as little more than a reactive discipline with little conceptual spine of its own. In the worst of cases, it makes us sound as if we are constantly second guessing tough real-world decisions from our armchairs; in the best case, it makes us appear like we are party-crashing (who invited the lawyer?).

For what are we in the end? One appealing view is that we are modest tradespersons who are the repositories of a long and fraught tradition and who may occasionally benefit from specific (if not unique) insights as a result of our peculiar position in the international system and the social world. There are the conversations we have between ourselves as highly specialized tradespersons, where we hammer out the details of how this or that mechanism works out. These are interesting to us, but they would elicit a polite yawn from almost everyone else. And then there are the conversations we have with others, in which we advance with a mixed of guarded protectiveness (as no doubt sometimes we should do) and inter-disciplinary hubris (wanting, in essence, to engage interdisciplinary conversations on our own terms).

Indeed, a more appealing view may be that, in the best of cases, we can be the sophisticated and even contrite articulators of our own crises and what they have done to the world rather than the other way round. The deep insight of Charlesworth was not that international law is about crises, or even that it is in crisis, but that it is a discipline of crisis. For many, the crisis is always outside the law; it is not specifically ours. In fact, it positively cannot be not ours since we are tasked with resolving it. Thus the outside crisis serves to mask our own, a crisis of our modes of understanding and, more often than not, the very real crises it repeatedly provokes in the world. The pandemic has, however, made painfully obvious, how international law is part of the very fabric of crises, neither sole enabler nor actively preventing them: the veneer of cosmopolitanism behind the brutal reassertion of nationalism; the stark limits of cooperation and international organization; the dominance of private agendas; the huge inequality.

Owning up to the sort of slow-motion crisis that is our discipline, then, might put us in an unenviable but intellectually more compelling spot: that of 
having gotten to the bottom of the pit and come back with the bad news that, alongside whatever few nuggets of wisdom we may have produced over the centuries but also the immense human toll and cost exacted, there really never was that much to be found: it was only a gold rush, and we all fell for it. Now we need to clean up, or at least own up to our own problematic legacy.

Finally, in an attempt to ground international law in everyday life, it may also be worth looking at what makes the production of scholarship possible. One thing that the pandemic has unmistakably done "for" scholarship is that it has changed some of its material conditions of production under a mix of neoliberal and political emergency conditions. In particular, it has introduced a series of significant temporal distortions. On the one hand, time seems to have ground to a halt as multiple commitments were cancelled, seemingly freeing up some space for imagination and contemplation. We live in an era, moreover, in which we have fully refined the art of conducting research projects in a networked, decentralized and delocalized fashion, meaning that the pandemic has hardly prevented the discipline from moving ahead, albeit in an increasingly disembodied and desocialized way. On the other hand, family obligations and (often heavily gendered) care work as well as the transition to online teaching have quickly redensified the little time that had been freed up. Rather than rebalancing international legal scholarship, the pandemic might end up reinforcing the same old voices, namely those who have the resources to thrive in a crisis. We should be wary.

In that vein, I think the question is how we could write differently? What would it mean to not write about Covid at all as international lawyers, or at least not directly? To be silent, for once? It is not as if the world cannot wait for our considered reflections on the virus. We are not in the race to produce a vaccine. Being silent could allow us to be mindful of the many issues that we are not focusing on as we chase the latest event. But being silent is hard when everyone and everything else has turned the volume up. How will that silence not be interpreted as dropping out, not caring or not living with the times? How might we reinvent an international legal scholarship of "looking elsewhere" or perhaps "looking beyond" when the challenges of the moment seem to call for all hands on deck?

Ultimately the discipline is defined by what we decide to write on and not write on. This non-contribution to the Covid and international law debate is written in this spirit: not wanting to entirely pass on the opportunity of a good crisis, yet feeling alienated by the discipline's omnivorous appetite for crises, and mindful of our responsibility to not surrender to the dominant crisis mode. 